THE INTER AMERICAN PRESS ASSOCIATION

Its Fight for Freedom of the Press, 1926-1960 
THIS PAGE INTENTIONALLY LEFT BLANK 
Latin American Monographs, No. 6

Institute of Latin American Studies

The University of TeXas 
THIS PAGE INTENTIONALLY LEFT BLANK 


\section{THE INTER AMERICAN PRESS ASSOCIATION: Its Fight for Freedom of the Press, 1926-1960}

Frm

BY MARY A. GARDNER

PUBLISHED FOR THE Institute of Latin American Studies BY THE UNIVERSITY OF TEXAS PRESS (aty 
Library of Congress Catalog Card No. 66-65208

Copyright (C) 1967 by Mary A. Gardner

All rights Reserved 
To those gallant Latin American journalists who have dedicated their pens to the cause of freedom 
THIS PAGE INTENTIONALLY LEFT BLANK 